\title{
Chimerism and Tolerance to Host and Donor in Severe Combined Immunodeficiencies Transplanted with Fetal Liver Stem Cells
}

\author{
Rosa Bacchetta, Bart A. E. Vandekerckhove, Jean-Louis Touraine, ${ }^{*}$ Mike Bigler, Silvana Martino, ${ }^{*}$ Lucette Gebuhrer, ${ }^{5}$ Jan \\ E. de Vries, Hergen Spits, and Maria-Grazia Roncarolo \\ Human Immunology Department, DNAX Research Institute, Palo Alto, California 94304; * INSERM U80, Hôpital E. Herriot, 69374 \\ Lyon, France; ${ }^{\ddagger}$ Clinica Pediatrica, University of Turin, 10126 Turin, Italy; and ${ }^{\S}$ Blood Transfusion Center, 69342, Lyon, France
}

\begin{abstract}
We have studied the peripheral $T$ cell repertoire of two patients with severe combined immunodeficiency who were successfully treated with human histocompatibility leukocyte antigen (HLA)-mismatched fetal liver stem cell transplantation. The patients presented a split chimerism. T cells were of donor origin, whereas the B cells / monocytes were of the host phenotype. Interestingly, the natural killer (NK) cells in one patient were donor derived and in the other patient of host origin. The NK cells were functional but did not have antihost or donor reactivity.

Despite the HLA mismatch between donor and host cells, complete tolerance was achieved in vivo, and a specific unresponsiveness of peripheral blood mononuclear cells from both patients toward the host cells was demonstrated in vitro. Nevertheless, we could isolate $\mathrm{T}$ cell receptor (TCR) $\alpha \beta, \mathrm{CD4}^{+}$or $\mathrm{CD8}^{+}, \mathrm{T}$ cell clones specifically reacting with HLA class I and II molecules of the host. The $\mathrm{CD4}^{+}$host-reactive $\mathrm{T}$ cell clones from both patients produced interleukins 2 and 5, interferon- $\gamma$, granulocyte / macrophage colony-stimulating factor but are specifically defective in interleukin 4 production. The frequencies of $\mathrm{CD8}^{+}$host-reactive $\mathrm{T}$ cells were high, and were in the same range as those observed for $\mathrm{CD8}^{+}$alloreactive $\mathrm{T}$ cells. In contrast, no donor-reactive $\mathrm{CD8}^{+} \mathrm{T}$ cells or host or donor-reactive $\mathrm{TCR} \gamma \delta^{+} \mathrm{T}$ cells were detected. These data indicate that, after fetal stem cell transplantation, donor-reactive, but not hostreactive cells, are deleted from the $\mathrm{T}$ cell repertoire. Therefore, a peripheral mechanism of suppression or clonal anergy, rather than clonal deletion, is involved in maintaining in vivo tolerance toward the host. (J. Clin. Invest. 1993. 91:1067-1078.) Key words: chimerism - fetal stem cell transplantation • host reactivity $\bullet$ severe combined immunodeficiency $\bullet$ transplantation tolerance
\end{abstract}

\section{Introduction}

Severe combined immunodeficiency $(\mathrm{SCID})^{1}$ encompasses a variety of congenital disorders characterized by abnormal lymphoid development. Although different genetic defects can be

Address reprint requests to Dr. Maria-Grazia Roncarolo, Human Immunology Department, DNAX Research Institute, 901 California Avenue, Palo Alto, CA 94304-1 104.

Received for publication 24 March 1992 and in revised form 24 September 1992.

J. Clin. Invest.

(c) The American Society for Clinical Investigation, Inc. $0021-9738 / 93 / 03 / 1067 / 12 \$ 2.00$

Volume 91, March 1993, 1067-1078 responsible for the disease, infants with SCID share a profound impairment of both cellular and humoral immune functions $(1,2)$. Bone marrow transplantation (BMT) from an histocompatible donor is the treatment of choice for these patients $(2,3)$. However, when HLA-identical donors are not available, transplantation with mismatched fetal liver stem cells, obtained from first trimester donors, has been shown to be successful (4). During the first trimester of gestation, the fetal liver is the major source of stem cells and is virtually free of mature $T$ cells capable of provoking a graft-versus-host disease (GVHD). In addition, SCID patients are naturally devoid of functional $T$ cells able to reject the transplant and therefore they do not require immunosuppressive conditioning therapy. However, in the absence of initial myeloablation, engraftment is generally confined to the $\mathrm{T}$ cell compartment, especially when host $B$ cells are present prior to the transplant. Despite this split chimerism, these subjects develop normal immunological functions including normal in vivo and in vitro antibodies responses $(5,6)$.

SCID chimeras represent one of the few examples of successful stem cell transplantation across HLA-mismatched barriers and therefore may serve as a model system to investigate the mechanisms of induction and maintenance of tolerance following allogeneic transplantation. The understanding of the underlying mechanisms may be useful, not only for allogeneic transplantation in immunodeficiencies, but also for transplanting patients suffering from lymphopoietic malignancies who lack histocompatible donors. Thus far, little is known about the extent of chimerism, the development of donor $T$ cell repertoire and the mechanisms of tolerance in patients reconstituted with mismatched stem cells $(4,7-10)$.

In this article, we analyze the peripheral $T$ cell repertoire of two SCID children reconstituted with fetal liver transplantation (FLT). In addition, we characterize the chimeric state of these two patients and we determine the frequencies of host and donor-reactive cells. It is shown that both patients, who are in good health, have T cell receptor (TCR) $\alpha \beta^{+}$and TCR $\gamma \delta^{+} \mathrm{T}$ cells of donor origin, whereas B cells and monocytes are of host origin. Interestingly, the extent of the chimerism varied. In one patient the natural killer (NK) cells express the HLA phenotype of the host, whereas in the other they are of donor origin. Furthermore, it is demonstrated that donor derived $\operatorname{TCR} \alpha \beta^{+}$. $\mathrm{CD}^{+}$and $\mathrm{CD} 8^{+}$host-reactive $\mathrm{T}$ cell clones could be isolated from both patients at high frequencies (11). However, these T cells were unresponsive toward the host HLA antigens in a

1. Abbreviations used in this paper: BMT, bone marrow transplantation; EBV-LCL, Epstein-Barr virus-transformed lymphoblastoid B cell line; FLT, fetal liver transplantation; GVHD, graft-vs.-host disease; MLC, mixed leukocyte culture; NK, natural killer; SCID, severe combined immunodeficiency; TCR, T cell receptor; TdR, thymidine. 
primary mixed leukocyte culture (MLC), suggesting that a peripheral regulatory mechanism of suppression or anergy, rather than clonal deletion, is involved in maintaining tolerance in these patients.

\section{Methods}

Clinical history and follow-up. Patient R.V. is $5 \mathrm{yr}$ old. He was born with a normal weight after an uncomplicated pregnancy. He had no family history of SCID. He became severely ill at $8 \mathrm{mo}$ of age with recurrent fever and suffered from intestinal and respiratory tract infections unresponsive to therapy. The delayed hypersensitivity skin test to tetanus toxoid (to which he had been vaccinated) was negative. The thymic shadow and pharyngeal lymphatic tissues were undetectable on $\mathrm{X}$-rays. Adenosine deaminase deficiency and purine nucleoside phosphorylase deficiency activity were within the normal range. In a 2-mo period the WBC markedly decreased, especially in the number of lymphocytes (from 2,800 to $800 / \mathrm{mm}^{3}$ ). The phenotype of the patient's PBMC showed profound decrease in the $\mathrm{CD} 2^{+}, \mathrm{CD}^{+}, \mathrm{CD}^{+}$, and $\mathrm{CD}^{+} \mathrm{T}$ cells $(<6 \%)$, whereas a relatively high percentage of $\mathrm{B}$ cells was present (Table I). The proliferative responses to mitogens were also strongly impaired. Serum IgG and IgA levels were far below the normal range and IgM levels were at the lowest levels of normality. Specific antibodies were undetectable.

Based on these clinical manifestations and biological findings, the diagnosis of SCID with absence of mature $T$ cells and presence of non functional B cells was made. The child was isolated in a sterile room and, because no HLA identical donor was available, he received fetal hematopoietic stem cell transplantations. Seven transplants from as many unrelated donors were given over a 6-mo period (from June to December 1987). In each case, a cell suspension of liver tissue, obtained from fetuses of gestational age ranging between 7 and $12 \mathrm{wk}$, was injected intravenously; in four cases, the autologous thymus was simul-

Table I. Immunologic Evaluation before and after Transplantation in Patient R.V.

\begin{tabular}{|c|c|c|c|c|}
\hline \multirow{3}{*}{$\begin{array}{l}\text { Lymphocyte number } \\
\qquad\left(\text { cells } / \mathrm{mm}^{3}\right)\end{array}$} & \multirow[t]{2}{*}{ Before } & \multicolumn{2}{|c|}{ After* } & \multirow[b]{2}{*}{$\mathrm{NV}^{\ddagger}$} \\
\hline & & \multirow{2}{*}{\multicolumn{2}{|c|}{2000}} & \\
\hline & 800 & & & $1800-4800$ \\
\hline \multicolumn{5}{|l|}{ Phenotype (\%) } \\
\hline $\mathrm{CD}^{+}$ & 5.2 & \multicolumn{2}{|c|}{64} & $60-90$ \\
\hline $\mathrm{CD}^{+}$ & 4.8 & \multicolumn{2}{|c|}{60} & $50-75$ \\
\hline $\mathrm{CD}^{+}$ & 3.5 & \multicolumn{2}{|c|}{11} & $35-45$ \\
\hline $\mathrm{CD}^{+}$ & 1.2 & \multicolumn{2}{|c|}{46} & $15-25$ \\
\hline $\mathrm{CD} 20^{+}$ & 29.4 & \multicolumn{2}{|c|}{25} & $5-10$ \\
\hline Proliferative response to & Patient & Control & Patient & Control \\
\hline mitogens $\left(\mathrm{cpm} \times 10^{-5}\right)$ & & & & \\
\hline Cells & 1.2 & 3.4 & 1.6 & 2.5 \\
\hline PHA & 4.4 & 52.4 & 26.4 & 60.4 \\
\hline ConA & 1.9 & 52.9 & 34.9 & 48.2 \\
\hline \multirow[t]{2}{*}{ PWM } & 2.1 & 34.5 & 9.7 & 25.7 \\
\hline & Patient & NV for age & Patient & NV for age \\
\hline \multicolumn{5}{|l|}{ Serum Ig levels $(m g / d l)$} \\
\hline IgG & 28 & $220-900$ & 237 & $420-1050$ \\
\hline $\operatorname{Ig} A$ & 2 & $16-84$ & 7 & $15-128$ \\
\hline IgM & 44 & $40-150$ & 38 & $48-170$ \\
\hline
\end{tabular}

* The following values were determined 4 mo after the first transplant.

Normal values. taneously injected. The number of cells in each transplant varied from $25 \times 10^{6}$ to $30 \times 10^{7}$. A rapid and persistent increase in the percentages of $T$ cells with mature phenotype was observed 4 mo after the first transplant and just before the seventh transplant. Peripheral blood lymphocyte counts 4 mo after reconstitution (Table I) were 2,000/ $\mathrm{mm}^{3}$ consisting of $64 \% \mathrm{CD} 2^{+}$cells and $60 \% \mathrm{CD}^{+}$cells. The number of $\mathrm{CD}^{+}{ }^{+}$and $\mathrm{CD} 8^{+}$cells also increased, but the $\mathrm{CD} 4 / \mathrm{CD} 8$ ratio was lower (0.24) compared to normal values (1.6-2.2), which was due to both lower number of $\mathrm{CD}^{+}$and higher number of $\mathrm{CD} 8^{+} \mathrm{T}$ lymphocytes. A more extensive phenotyping performed on RV-PBMC $3 \mathrm{yr}$ after transplantation is shown in Fig. 1. All T lymphocyte populations were reconstituted. However, the proportion of $\mathrm{TCR} \gamma \delta^{+} \mathrm{T}$ cells was $40 \%$ of the $\mathrm{CD}^{+}$cells, which is much higher than normal $(1-10 \%)$ (12); all TCR $\gamma \delta^{+} \mathrm{T}$ cells were $\mathrm{V} \delta 2^{+}$and $\mathrm{CD}_{45 \mathrm{RO}^{+}}$(not shown). The $\mathrm{CD}^{+} / \mathrm{CD}^{+}{ }^{+}$cell ratio was persistently inverted $(0.58)$. The percent-

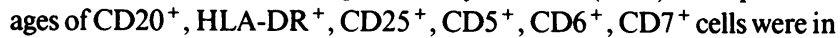
the normal range. $2 \%$ of the lymphocytes expressed CD34. Cells with NK phenotype were present in low amounts and expressed low levels of CD16 and CD56. The same two markers checked 9 mo later on PBMC showed an increase in the CD56 expression whereas the CD16 expression remained very low. In parallel with the appearance of mature $T$ cells, the proliferative responses to mitogens became normal. The serum immunoglobulins remained low after transplantation and the patient had immunoglobulin injections every $3 \mathrm{wk}$. The values of IgM ranged between 30 and $60 \mathrm{mg} / \mathrm{dl}$, but levels of $200 \mathrm{mg} / \mathrm{dl}$ were also measured. The IgG values were determined before each immunoglobulin administration and ranged from 400 to $500 \mathrm{mg} / \mathrm{dl}$.

Patient S.P. is now 18 yr old. His clinical history has been already described in detail (5). In brief, because he had a family history of SCID, he was placed in a sterile environment soon after birth, before the onset of the disease. Analysis of his PBMC confirmed that he was affected with SCID with lack of $T$ cells, whereas B cells were present. He received two allogeneic fetal liver transplantations from two unrelated donors. In both cases the autologous fetal thymus was simultaneously injected. The history of the reconstitution was comparable to that of patient R.V. with the exception of the percentages of TCR $\gamma \delta^{+} \mathrm{T}$ cells, which were in the normal range (2-5\%). However, in this patient the presence of TCR $\gamma \delta^{+} \mathrm{T}$ cells was first investigated $13 \mathrm{yr}$ after transplantation. After reconstitution ( $3 \mathrm{yr}$ ), endogenous immunoglobulins were produced and no further medication was given.

Cell lines. The Epstein-Barr virus-transformed lymphoblastoid B cell line (EBV-LCL) of patient R.V. (UD153), his father (UD154), his mother (UD155), and the allogeneic EBV-LCL were generated by EBV infection of PBMC.

The T cell lines were obtained from patients' PBMC and parents' PBMC after PHA $(0.1 \mu \mathrm{g} / \mathrm{ml})$ stimulation in the presence of IL-2 $(20$ $\mathrm{U} / \mathrm{ml}$ ). The $\mathrm{T}$ cell line of host origin (Blast 87 ) was obtained from pretransplant RV-PBMC which have been activated with PHA. These cells were stimulated twice with feeder cell mixture consisting of $5 \times$ $10^{5} / \mathrm{ml} \mathrm{PBMC} \mathrm{(irradiated} \mathrm{at} \mathrm{4,000} \mathrm{rad),} 5 \times 10^{4} \mathrm{JY}$ EBV-LCL (irradiated at 5,000 rad), and PHA and expanded in the presence of IL-2, IL-4 $(200 \mathrm{U} / \mathrm{ml})$, and IL-7 $(10 \mathrm{ng} / \mathrm{ml})$. All T cell lines were weekly restimulated with the feeder cell mixture and maintained in culture with IL-2.

HLA typing. HLA typing of both patients was carried out on purified $T$ and $B$ cells, $T$ cell clones, EBV-LCL, and NK clones using a cytotoxicity assay previously described (13). HLA-DR was further determined on purified $\mathrm{T}$ cells, $\mathrm{B}$ cells, and monocytes by polymerase chain reaction (PCR)/oligotyping as described (13).

Establishment of $T$ cell clones. Host-reactive $\mathrm{TCR} \alpha \beta^{+} \mathrm{T}$ cell clones were obtained from PBMC of patient R.V. either after activation with aCD2 $\mathrm{mAb}$ or with the host's EBV-LCL, in the presence of IL-2. $10^{5}$ PBMC were activated with a mitogenic combination of X11-1 and D66 aCD2 mAb (1:2,000 of ascites) (a kind gift of Dr. A. Bernard, Hôpital de l'Archet, Nice, France) in 96-well plates. $3 \mathrm{~d}$ later, $20 \mathrm{U} / \mathrm{ml}$ of IL-2 were added. After $7 \mathrm{~d}$, the $\mathrm{CD} 8{ }^{+}$cells were sorted and cloned at one cell per well by using a FACStar Plus (Becton, Dickinson \& Co., Mountain View, CA ). Individual cells were collected in wells filled with the feeder 

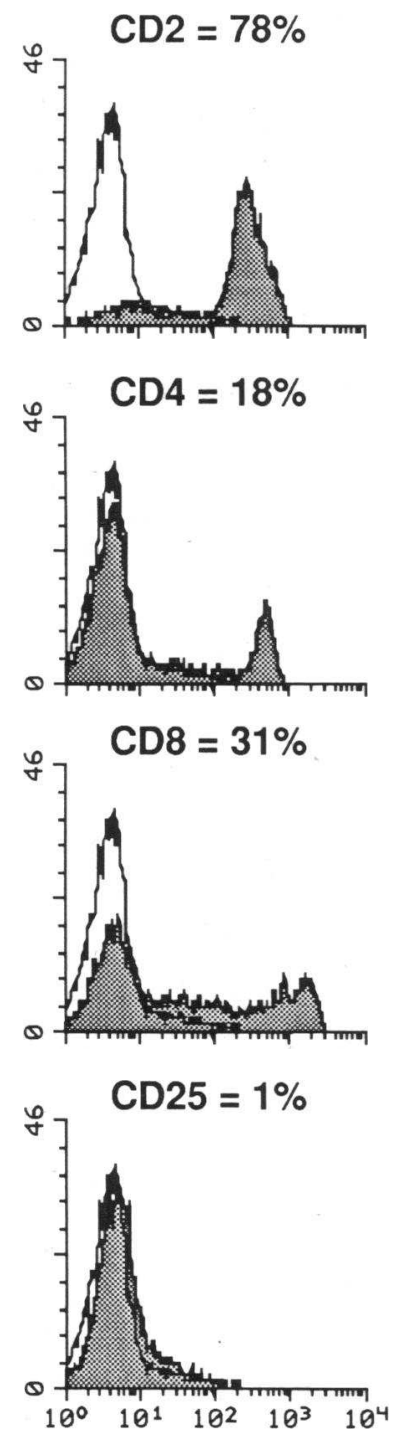
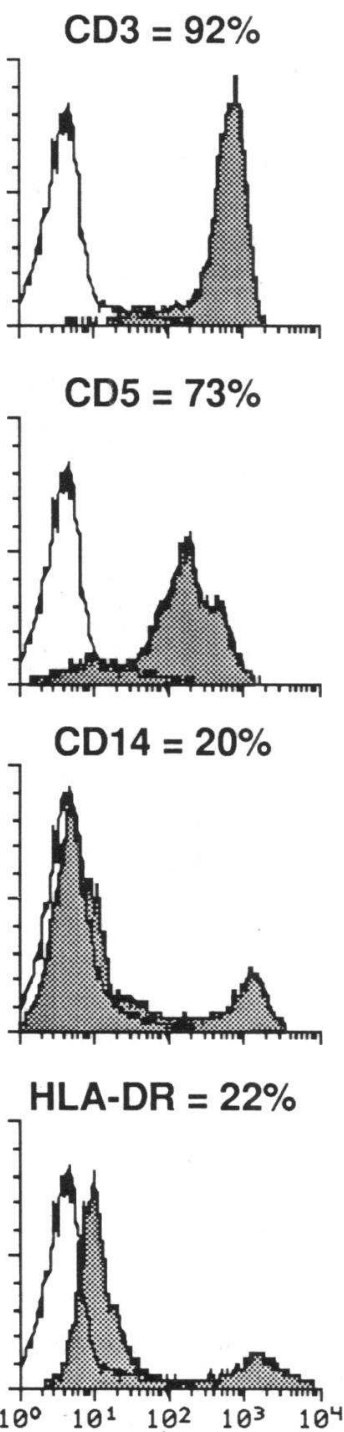
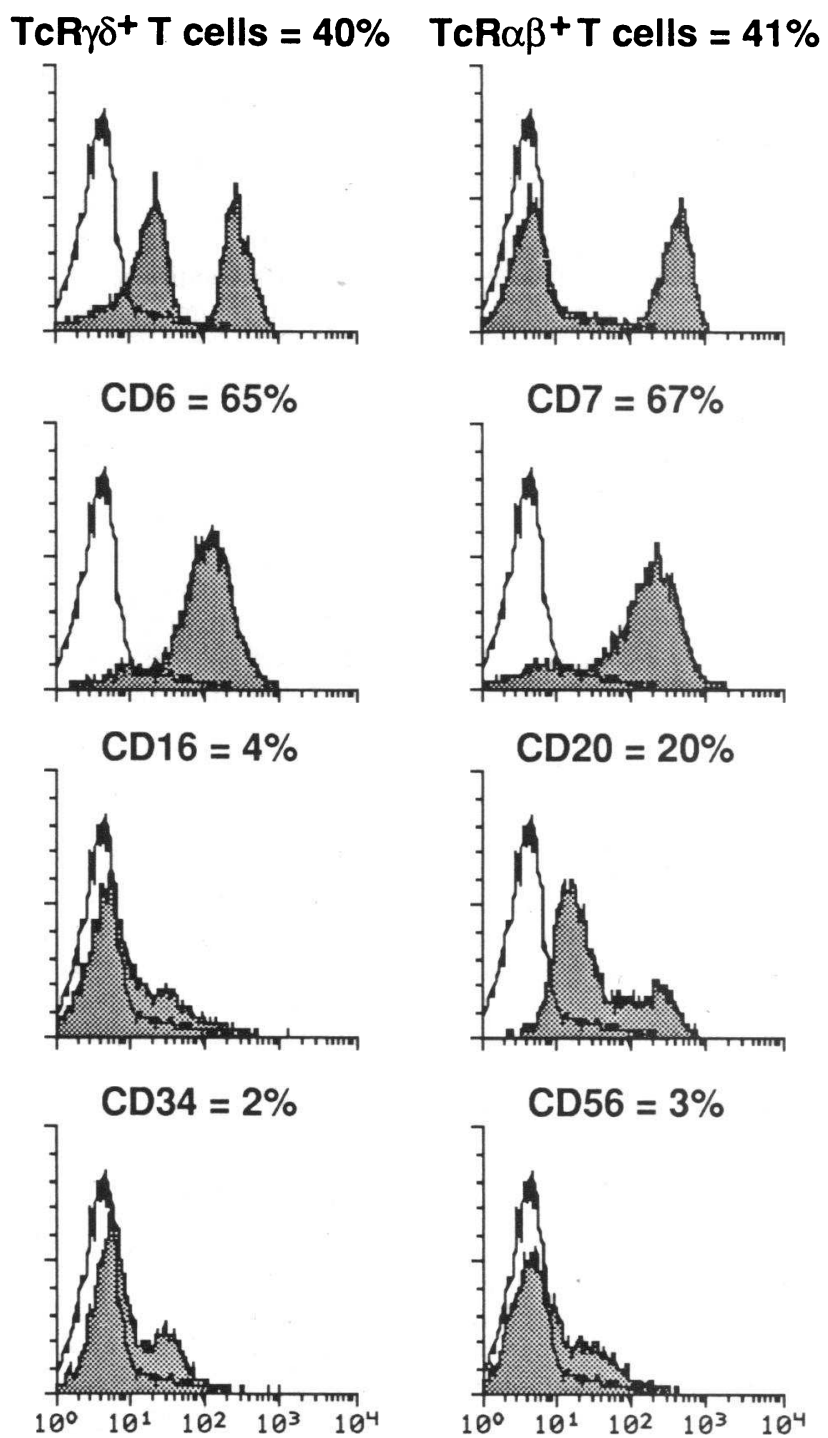

Figure 1. Phenotype of peripheral blood lymphocytes of patient R.V. $3 \mathrm{yr}$ after reconstitution with fetal liver stem cell transplantations. Cells were stained with the different mAbs described in Methods (filled histograms) and with isotype control mAbs (clear histograms). For the CD14 staining the FACS gate included total PBMC.

cell mixture. After $1 \mathrm{wk}$, fresh medium with $20 \mathrm{U} / \mathrm{ml}$ of IL-2 was added. 1 wk later, growing cultures were transferred into 24-well plates and restimulated with the feeder cell mixture. The clones were then expanded in medium containing IL-2. Among the $138 \mathrm{~T}$ cell clones screened, four displayed host reactivity.

To obtain host-reactive $\mathrm{T}$ cell clones after Ag-specific stimulation, an MLC was performed in which $10^{5}$ PBMC were activated with $10^{4}$ irradiated EBV-LCL of the host (UD153). After $3 \mathrm{~d}$ of culture, fresh medium containing $10 \mathrm{U} / \mathrm{ml}$ of IL-2 was added. $8 \mathrm{~d}$ after onset of the cultures, the remaining cells were restimulated with UD153 (II MLC). $7 \mathrm{~d}$ later, a proportion of the responder cells was stimulated for a third time with UD153 (III MLC), whereas the other part was expanded with feeder cells. All cells from the III MLC and sorted CD4 ${ }^{+} \mathrm{T}$ cells from the II MLC that had been expanded with feeder cells, were cloned by limiting dilution at 0.3 cells per well. 52 of the $218 \mathrm{~T}$ cell clones obtained after specific stimulation, were host-reactive. Host-reactive T cell clones from patient S.P. were established as previously described (11).

The $\mathrm{TCR} \gamma \delta^{+} \mathrm{T}$ cell clones were obtained from sorted $\mathrm{CD} 4^{-} \mathrm{CD} 8{ }^{-}$ cells and cloned according to the above procedure.

Establishment of $\mathrm{NK}$ cell clones. $\mathrm{CD} 16^{+} \mathrm{CD} 56^{+}$cells were isolated by cell sorting from RV-PBMC and expanded with feeder cell mixtures and IL-2. After $10 \mathrm{~d}, \mathrm{CD} 56^{+} \mathrm{CD} 16^{+} \mathrm{CD}^{-}$cells were sorted for a second time, to eliminate contaminating $\mathrm{T}$ cells, and cloned by limiting dilution, at 10,5, and 1 cells per well. NK cells from patient S.P.-PBMC were enriched using a Percoll gradient centrifugation and $\mathrm{CD} 56^{+} \mathrm{CD} 16^{+}$cells were purified using the FACStar plus as previously described (14). Clones were expanded using the culture conditions described above.

Monoclonal antibodies. Monoclonal antibodies against the following antigens were used: CD2 (anti-Leu5b); CD3 $\epsilon$ (anti-Leu4); CD3 $\delta$ (mAb Sp64; generously provided by Dr. C. Terhorst, Harvard Medical School, Boston, MA) (15); TCR $\gamma \delta$ (TcR $\delta_{1}$; a kind gift of Dr. M. Brenner, Dana Farber Cancer Institute, Boston, MA $) ; \delta_{1}\left(\delta \mathrm{TCS}_{1} ; \mathrm{T}\right.$ Cell Sciences, Cambridge, MA) and $\mathrm{V} \delta_{2}$ (BB3; a gift of Dr. L. Moretta, Genova, Italy) (16); TcR $\alpha \beta$ (BMA31; T Cell Sciences); CD4 (antiLeu3a); CD5 (anti-Leu 1); CD6 (anti-Leu 17); CD7 (anti-Leu9); CD8 (anti-Leu2b); CD16 (anti-Leu 1 1a); CD20 (anti-Leu 16); CD25 (antiIL-2 receptor $\alpha$ ); CD34 (IDM34; AMAC, Inc., Westbrook, ME); CD45RO (UCHL-1); CD56 (anti-Leu 19); CD57 (anti-Leu7); HLADR (anti-HLA-DR); Leu8 (anti-Leu8). All mAbs were purchased from Becton-Dickinson \& Co. (Mountain View, CA), unless otherwise 
noted. CD11a (anti-LFA-1 $\alpha$ ), CD18 (anti-LFA-1 $\beta$ ), CD28 (antiCD28, L293), CD29 (anti-VLA $\beta$ ), and CD49 (anti-VLA $\alpha 4$ ) mAbs were kindly provided by L. Lanier (DNAX Research Institute). Hybridoma's producing mAbs against allotypic HLA determinants MA2.1 (anti-HLA-A2) and SFR3-DR5 (HLA-DR5), which recognize both HLA-DR 11 and HLA-DR 12 subtypes, were obtained from the American Type Culture Collection (Rockville, MD).

Fluorescence analysis. For detection of cell surface antigens, $10^{5}$ cells were labeled with $\mathrm{mAbs}$ and FITC-labeled goat anti-mouse antibodies or with FITC or phycoerythrin conjugated mAbs. The cells were incubated for 30 min with the appropriate $\mathrm{mAb}$ in PBS with $0.1 \% \mathrm{BSA}$ and $\mathrm{NaN}_{3}$ in all staining experiments as described (11).

To detect the cytoplasmic CD3 proteins, cells were fixed in PBS containing $0.1 \%$ paraformaldehyde at $4^{\circ} \mathrm{C}$ overnight. After two washes, cell membranes were permeabilized by treatment with PBS containing $0.1 \%$ Triton X-100 on ice for 30 min and then stained.

Proliferation and cytotoxic assays. The proliferative response of the patients' PBMC towards the HLA Ags of the host was tested in a MLC by stimulating $2 \times 10^{5}$ PBMC with $2 \times 10^{4}$ irradiated host EBV-LCL or HLA-matched monocytes in round-bottomed 96-well plates. After $4 \mathrm{~d}$ of incubation at $37^{\circ} \mathrm{C}$ in a humidified atmosphere of $5 \% \mathrm{CO}_{2}$, the cultures were pulsed overnight with $1 \mu \mathrm{Ci}$ of tritiated thymidine $\left(\left[{ }^{3} \mathrm{H}\right]\right.$ TdR), harvested onto fiberglass filters and $\left[{ }^{3} \mathrm{H}\right] \mathrm{TdR}$ incorporation was determined by scintillation spectroscopy. Proliferative responses of host-reactive T cell clones were tested as previously described (11).

Cytotoxic activity of NK cells and T cell clones was measured in a standard $4 \mathrm{~h}{ }^{51} \mathrm{Cr}$-radioisotope release assay (11). K562 (erythroleukemia), Daudi (Burkitt lymphomas), and JY (EBV-LCL) were used as NK-sensitive targets.

Determination of lymphokine production. To evaluate lymphokine production, resting host-reactive $\mathrm{T}$ cell clones collected 8-10 d after stimulation with the feeder cell mixture, were washed and stimulated with the host's EBV-LCL or with $10 \mu \mathrm{g} / \mathrm{ml}$ of ConA at $10^{6}$ cells $/ \mathrm{ml}$, as described (17). After $22 \mathrm{~h}$ of incubation the supernatants were harvested and tested. The presence of IL-2, IFN- $\gamma$, IL-4, IL-5 and GMCSF was quantified by immunoenzymetric assays performed as previously described $(17,18)$. Sensitivity of each assay was $20 \mathrm{pg} / \mathrm{ml}$ for IL-2, IL-5 and GM-CSF; $40 \mathrm{pg} / \mathrm{ml}$ for IL4; $100 \mathrm{pg} / \mathrm{ml}$ for IFN- $\gamma$.

Limiting dilution analysis for lymphokine secreting and cytotoxic $T$ cells. The frequency analysis was performed as previously described (19). Briefly, $\mathrm{CD} 8^{+} \mathrm{T}$ cells, obtained by cell sorting on a FACStar Plus, from PHA-activated PBMC of patient R.V. and freshly isolated PBMC of patient S.P., were seeded manually at 0 (for background determination), 1 (for determination of cloning efficiency), 10 , and 20 cells per well in 96-well round-bottomed plates, with feeder cell mixture. After 1 wk, fresh medium and IL-2 were added. After an additional $5 \mathrm{~d}$ the cultures were washed, split, and tested against different targets for determination of cytotoxic cells frequencies. To determine IL-2-secreting cells, the cultures were incubated for an additional week. Subsequently, they were stimulated with different EBV-LCL. The supernatants were harvested after $20 \mathrm{~h}$ and IL-2 activity was assayed in duplicate on the mouse cell line CTLL-2 as described (18).

\section{Results}

HLA typing and detection of chimerism. In order to confirm engraftment and to evaluate the extent of chimerism, HLA typing of patients' PBMC was performed at different times after the transplantations. The HLA typing of the patients and the engrafted donors is shown in Table II. In patient R.V., the presence of only one population of cells with an allogeneic HLA phenotype was detected by serology and PCR analysis carried out on PBMC, indicating that only one of the seven unrelated transplants was engrafted. HLA typing of the fetal material before the transplantations was not performed, therefore it is not known which transplant has led to the successful engraftment. The donor and host cells shared one of the HLA$A$ and $-\mathrm{C}$ alleles (HLA-A2; Cw4), but they were mismatched for the other HLA alleles.

HLA typing of the PBMC of patient S.P., who received FLT from two different donors, revealed stable engraftment of cells from the second donor (10; Table II). In addition, 10$20 \%$ of the circulating T cells were derived from the first transplant. The HLA phenotypes of both donors were completely mismatched with those of the host.

Standard HLA typing carried out on purified TCR $\alpha \beta^{+}$and TCR $\gamma \delta^{+} \mathrm{T}$ cells, B cells, NK cells, and freshly isolated monocytes showed that in both patients the T cells were exclusively of donor origin. In patient S.P., TcR $\alpha \beta^{+}$and $\gamma \delta^{+} \mathrm{T}$ cells derived from both the first and the second donor were detectable. In contrast, B cells and monocytes, which were already present before the transplants, remained of host origin ( Table II). Interestingly, the NK cells in the patients were of different origin. The NK cells in patient R.V. were of donor origin, whereas in S.P. they were of host origin. The chimerism was confirmed in both patients by phenotyping $>100 \mathrm{TcR} \alpha \beta^{+} \mathrm{T}$ cell clones, 30 $\mathrm{TcR} \gamma \delta^{+} \mathrm{T}$ cell clones, EBV-LCL, and NK cell clones ( $108 \mathrm{NK}$ clones from patient R.V., 85 NK clones from S.P.). An example of this phenotyping is shown in Fig. 2. An anti-HLA-DR5 mAb, which recognizes both HLA-DR 11 and HLA-DR 12 subtypes, was used to detect cells of donor origin in patient R.V. and an anti-HLA-A2 mAb was used to identify donor derived cells in patient S.P. All TCR $\alpha \beta^{+}$and $\gamma \delta^{+}$T cell clones, isolated from both patients, were of donor origin (HLA-DR5 ${ }^{+}$in R.V. and HLA-A2 ${ }^{+}$in S.P.). TCR $\alpha \beta^{+}$T cell clones included TTspecific $\mathrm{T}$ cell clones (20), host-reactive (see below) and alloreactive $T$ cell clones (21). EBV-LCL failed to stain with HLADR5 or HLA-A2 specific mAbs, indicating that they were of host origin. RV-NK cell clones were of donor origin (HLA$\mathrm{DR}^{+}$), whereas SP-NK cell clones were all host derived (HLA-A2 ${ }^{-}$).

Table II. HLA Typing and Chimerism in PBMC of Patients R.V. and S.P. after Reconstitution with Fetal Liver Stem Cells

\begin{tabular}{|c|c|c|c|c|c|c|c|}
\hline \multirow[b]{2}{*}{ Patient } & \multirow[b]{2}{*}{ Origin } & \multicolumn{5}{|c|}{ HLA locus } & \multirow[b]{2}{*}{ Type of cells } \\
\hline & & A & $\mathrm{C}$ & B & DR & DQ & \\
\hline \multirow[t]{2}{*}{ R.V. } & host & $2-31$ & w4-w7 & $37-62$ & $8-10$ & $4-5$ & B cells, monocytes \\
\hline & donor & $2-30$ & w4 & $8-35$ & $11-13$ & $6-7$ & T cells, NK cells \\
\hline \multirow[t]{3}{*}{ S.P. } & host & $3-33$ & w6 & $14-47$ & $4-11$ & $7-7$ & $\begin{array}{l}\text { B cells, monocytes, } \\
\text { NK cells }\end{array}$ \\
\hline & 1st donor & $2-11$ & w4 & $27-62$ & $1-8$ & 5 & $20 \%$ T cells \\
\hline & 2nd donor & $1-2$ & w7 & $8-18$ & $3-9$ & $3-2$ & $80 \%$ T cells \\
\hline
\end{tabular}



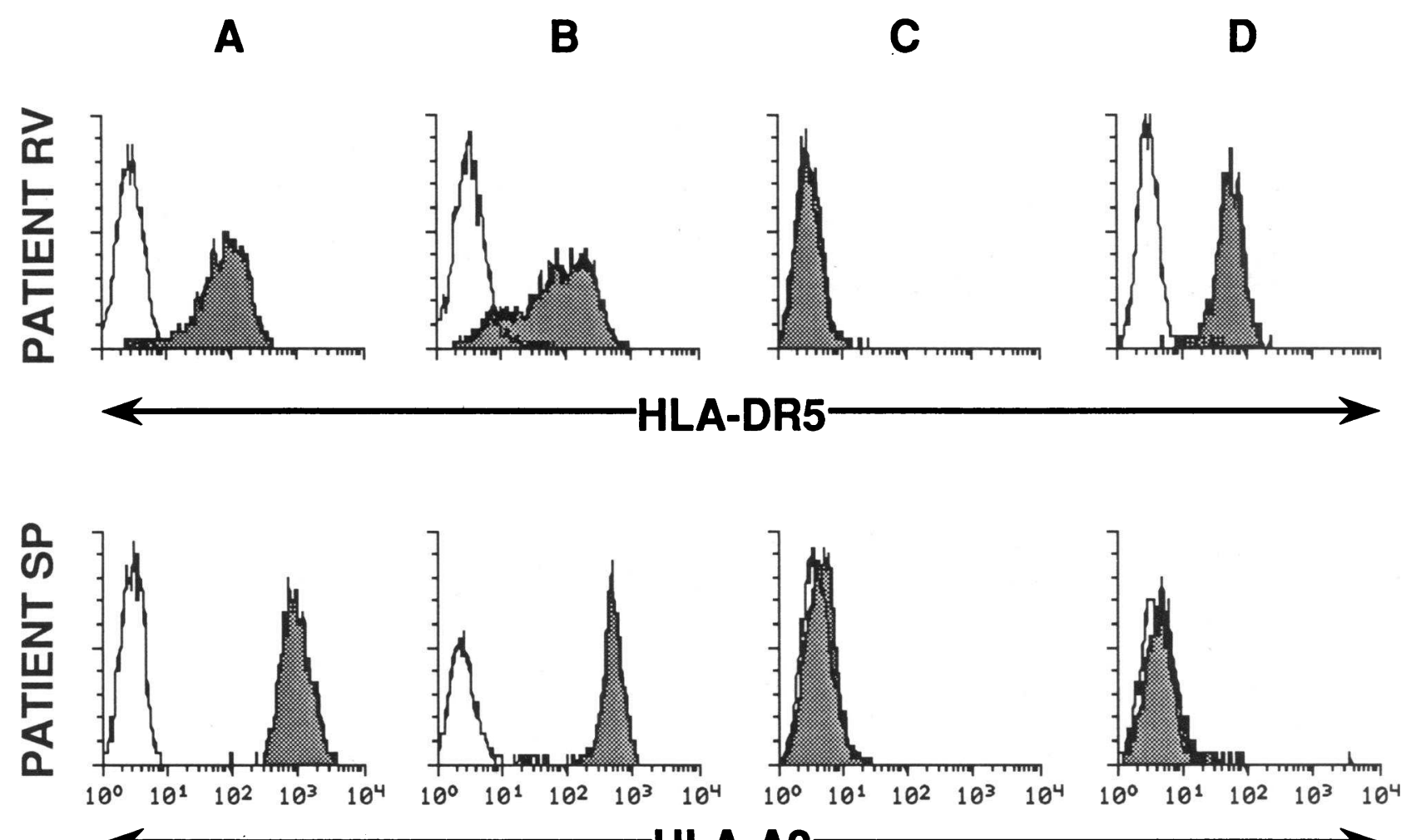

Figure 2. HLA phenotype of cell lines isolated from PBMC of patients R.V. and S.P. The donor cells (filled histograms) are recognized by antiHLA-DR5 mAb in patient R.V. and by anti-HLA-A2 mAb in patient S.P. The HLA Ags of TCR $\alpha \beta^{+}(A)$ and TCR $\gamma \delta^{+}(B)$ T cell clones, EBV-LCL $(C)$, and NK cell lines $(D)$ are shown for each patient.

Characterization of NK cells. The NK cells of patient R.V. appeared in the peripheral blood late after reconstitution. HLA typing revealed that they derived from the fetal donor. To determine their differentiation stage, we studied the expression of different markers such as CD16, CD57, Leu8, and intracytoplasmic CD3 (cCD3), which distinguish adult NK cells from immature NK cells (22-25). Similarly to immature NK cells, freshly isolated NK cells from patient R.V. expressed low amounts of CD16 (Fig. 1) and CD57 (not shown), whereas the majority of the NK cells present in the peripheral blood of normal donors have high expression of both markers (25). RV-NK cell line $\mathrm{J} 201$ was $\mathrm{CD} 2^{+}, \mathrm{CD}^{-}{ }^{-}, \mathrm{CD} 56$ bright, weakly expressed the CD16 marker and was negative for CD57 and Leu8 (Fig. 3). Furthermore, CD16 expression on RV-NK cell clones varied from negative to weakly positive. However, in contrast to immature NK cells, no $\mathrm{cCD} 3 \epsilon$ and $\delta$ chains could be detected in the RV-NK cell line ( Fig. 3) and RV-NK cell clones (not shown). The phenotype of host derived NK cells of patient $\mathrm{SP}$ was comparable to that of adult NK cells (25). Freshly isolated SP-NK cells expressed high levels of CD16 and CD57. SP-NK cell lines and SP-NK cell clones were $\mathrm{CD}_{2}{ }^{+}$$\mathrm{CD} 3^{-} \mathrm{CCD} 3^{-} \mathrm{CD} 56^{+} \mathrm{CD} 57^{-}{ }^{-}{ }^{-}$eu $8^{-}$and had high expression of CD16 (not shown).

The cytotoxic activity of NK cell clones isolated from both patients is shown in Fig. 4. They displayed high cytotoxic activity against the NK sensitive cell lines K562, Daudi, and JY. None of the NK clones was significantly cytotoxic for donor or host cells.
Proliferative responses of freshly isolated PBMC of the patients to host, parental, and allogeneic cells. To investigate whether the in vivo tolerance between donor $T$ cells and host cells was also present in vitro, we studied the proliferative responses of PBMC of the two patients toward HLA-incompatible cells of host origin in primary MLC, in the absence of exogenous cytokines. PBMC were isolated from patient S.P. 16 yr and from patient R.V. 3 yr after transplantation, respectively. The EBV-LCL of host origin was used as stimulator for patient's RV-PBMC. In patient S.P., who is EBV seropositive, purified monocytes matched for the HLA-DR molecules of the host were used as stimulators. The proliferative responses to the EBV-LCL or to the monocytes of the parents and to thirdparty EBV-LCL or monocytes were also evaluated. Results shown in Table III demonstrate that patients' PBMC proliferated vigorously when stimulated with parental and unrelated mismatched EBV-LCL or monocytes. In contrast, very low proliferative responses were observed when PBMC from both patients were stimulated by host cells. PBMC of normal donors which showed normal proliferative responses to all cells used as stimulators, were tested in parallel. Engagement of the TCR in the absence of co-stimulatory signal mediated by CD28/B7 interaction results in an unresponsive state of the $T$ cells (26). This unresponsiveness can be restored by the addition of anti$\mathrm{CD} 28 \mathrm{mAb}$ (27). The addition of different concentrations of anti-CD28 mAb did not reverse the unresponsiveness of the PBMC of patient SP towards the host cells (Table IV), suggesting that it was not due to insufficient CD28/B7 interaction. In 


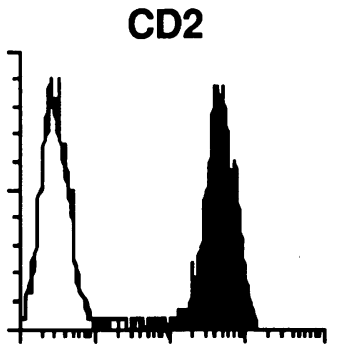

Leu8

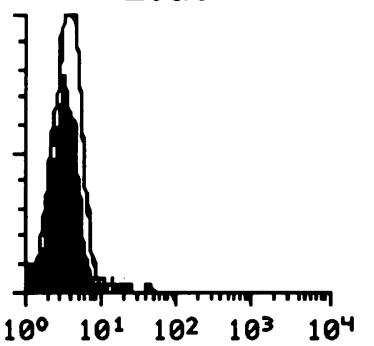

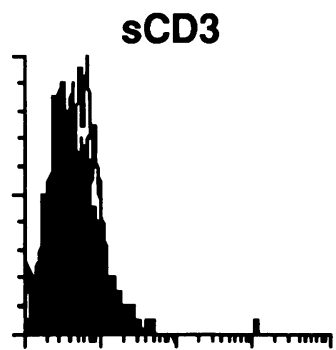

CD16

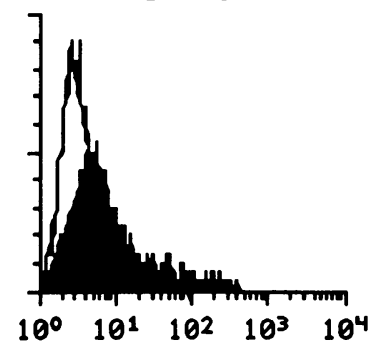

cCD3 $\delta$

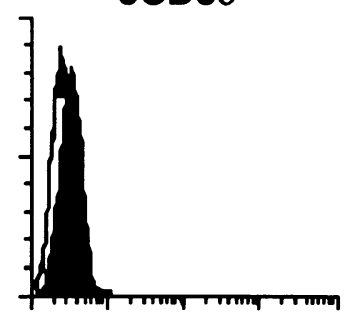

CD56

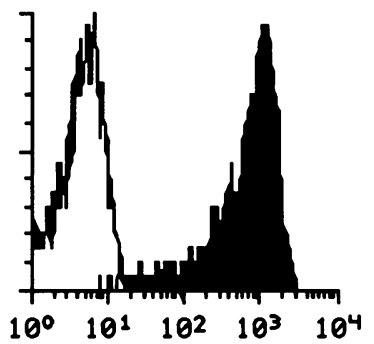

CCD3E

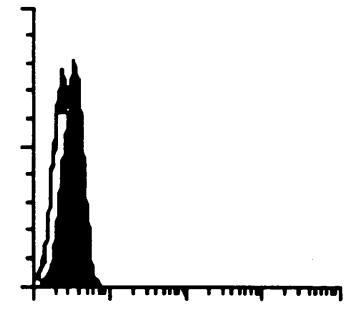

CD57

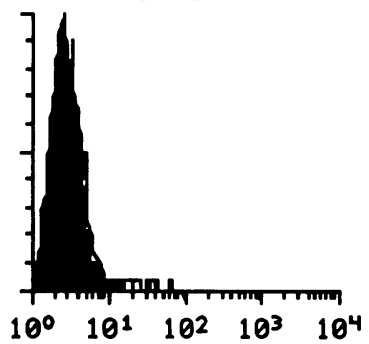

Figure 3. Phenotype of a donor-derived NK cell line (RV-J201) of patient R.V. Filled histograms represent RV-J201 stained with FITC- or phycoerithrin conjugated mAbs (see Methods), and clear histograms represent the same cells stained with isotype control mAbs. sCD3, surface $\mathrm{CD} 3 ; \mathrm{cCD} 3 \delta$ and $\epsilon$, intracytoplasmic CD3.

addition, various concentrations of exogenous IL-2, which has been shown to break tolerance in many models $(26,28,29)$, failed to restore specific responsiveness in the primary MLC, despite the fact that considerable levels of non specific proliferation were induced (Table IV). Similarly, IL-4, which has T cell growth promoting activity (30), had no effects.

Isolation and characterization of host-reactive $T$ cell clones. We previously reported that $\mathrm{CD}^{+}$and $\mathrm{CD} 8^{+} \mathrm{T}$ cell clones specific for the HLA determinants of the host could be isolated from PBMC of patient S.P., after stimulation with host EBVLCL, despite the in vivo tolerance and the in vitro unresponsiveness to the mismatched cells of the host (11). Comparable host-reactive $\mathrm{T}$ cell clones were obtained after polyclonal activation of the PBMC with PHA (21). Host-reactive T cells are also present in the PBMC of patient R.V. Host-reactive T cell clones were obtained both after polyclonal stimulation of the PBMC with aCD2 mAbs and after activation with the host EBV-LCL (UD153) in the presence of IL-2. All clones were $\mathrm{TcR} \alpha \beta^{+} \mathrm{CD} 2{ }^{+} \mathrm{CD}^{+}{ }^{+}$. They expressed normal levels of CD1 1a/CD18 and CD49/CD29. The fluorescence intensity of CD28 expression was similar to that of control alloreactive $T$ cell clones (obtained from the patients and from normal donors) and varied from dim to bright. Proliferative responses, cytotoxic activity and IFN- $\gamma$ production of 20 representative T cell clones out of 56 host-reactive $T$ cell clones obtained from patient R.V. are shown in Table V. The $\mathrm{CD} 4^{+} \mathrm{T}$ cell clones proliferated in response to the EBV-LCL UD153 of host origin, whereas they did not respond to allogeneic EBV-LCL which did not share any relevant HLA Ags with the host (not shown). For some of the $\mathrm{CD} 4^{+} \mathrm{T}$ cell clones the proliferative responses to UD153 were persistently low, however the IFN- $\gamma$ production, which was tested simultaneously, was high. The $\mathrm{CD} 8^{+} \mathrm{T}$ cell clones were highly cytotoxic against UD153 and against the host PHA-activated T cell blasts and they produced variable amounts of IFN- $\gamma$ when stimulated by the host cells. Proliferative responses of the $\mathrm{CD}_{4}{ }^{+}$and cytotoxic activities of the
$\mathrm{CD}^{+}$host-reactive $\mathrm{T}$ cell clones of patient R.V. were specifically blocked in the presence of anti-HLA class II and class I mAbs, respectively (not shown).

To further study the specificity of these clones, their ability to recognize the parental cells was tested. In Table VI it is shown that some of the $\mathrm{CD}^{+}{ }^{+}$host-reactive clones (A24, B44, $2 / 3,2 / 7$, and $2 / 13$ ) were specifically cytotoxic for the $T$ cell blasts of the father, sharing the HLA-A31, Cw4, B62 with the host, and not for the cells of the mother. The other clones were cytotoxic against the mother's PHA-activated T cell blasts, that share HLA-A2, Cw7, B37 with the patient. In addition, none of the clones tested were cytotoxic against the $T$ cell blasts of the donor. In particular, no T cell clones specific for HLA-A2 antigen, shared by donor and host, could be identified. This suggests that host-reactivity is directed only against the HLA Ags of the host which are not present on the donor cells.

Lymphokine production profile. The pattern of lymphokine production by $\mathrm{CD}^{+}$and $\mathrm{CD} 8^{+}$host-reactive $\mathrm{T}$ cell clones of patient RV, after ConA activation, is shown in Table VII. As previously described for $\mathrm{T}$ cell clones obtained from normal donors (31), both subsets of host-reactive T cell clones produced high amounts of IFN- $\gamma$ and synthesize granulocyte/macrophage colony-stimulating factor (GM-CSF), IL-2, and IL5. In contrast, both $\mathrm{CD}^{+}{ }^{+}$and $\mathrm{CD} 8{ }^{+}$host-reactive $\mathrm{T}$ cell clones were unable to produce IL-4, whereas the majority of $\mathrm{T}$ cell clones isolated from normal donors synthesize IL-4 (31). The lack of IL-4 production by host-reactive T cell clones was confirmed at transcriptional level by PCR (not shown).

Frequency analysis of $\mathrm{CD}^{+}$host-reactive $T$ cells. To investigate the frequency of host-reactive $T$ cells, a limiting dilution assay was performed. Results of one representative experiment of three are illustrated in Table VIII. In patient R.V. the frequency of $\mathrm{CD}^{+}$cytotoxic cells reacting against the host EBVLCL (UD153) was 1:902, and the frequency of cells reactive against the allogeneic EBV-LCL (K395) was 1:179. The frequencies of $\mathrm{CD}^{+}$IL-2 producing cells towards the same EBV- 

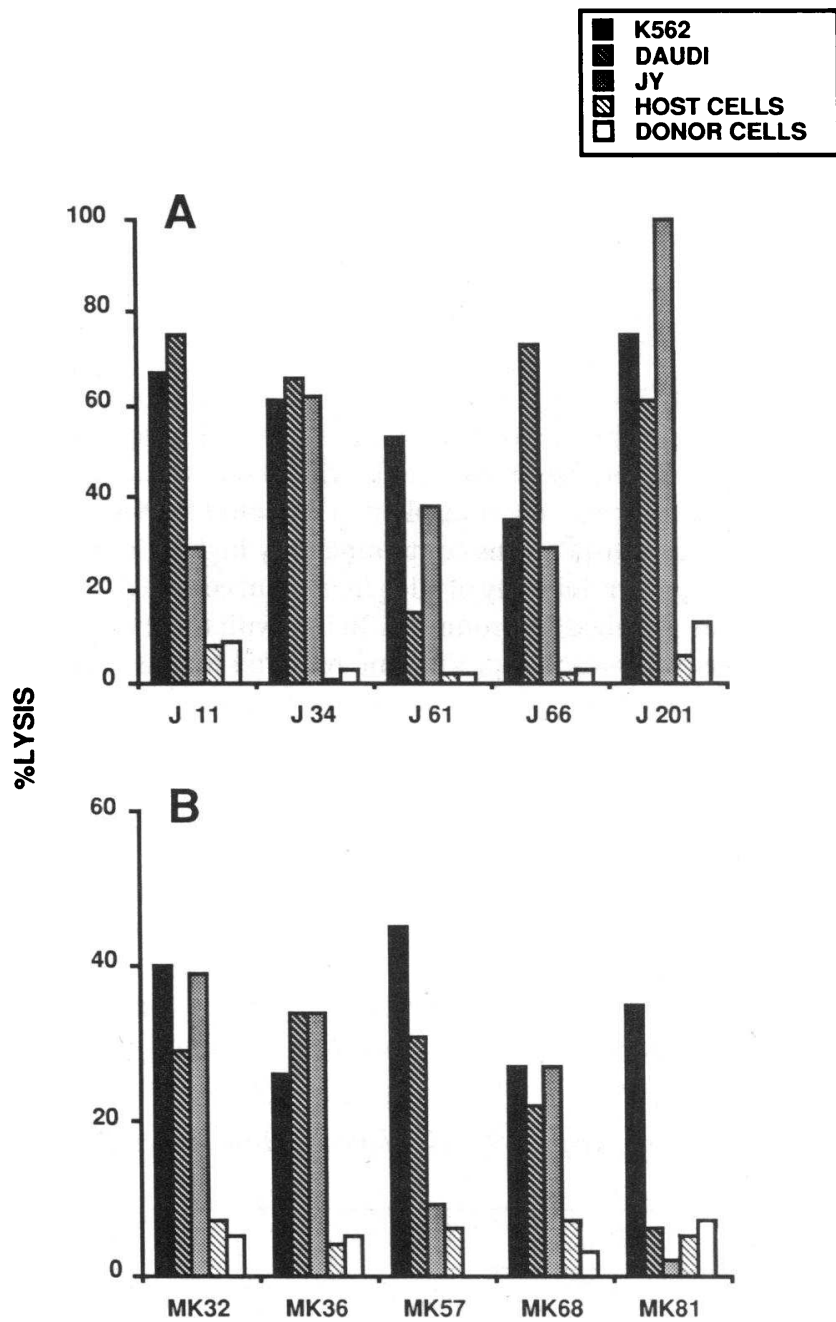

Figure 4. Lytic activity of donor-derived NK cells of patient R.V. and host-derived NK cells of patient S.P., after reconstitution. $(A) \mathrm{RV}$-NK clones and $(B)$ SP-NK clones. E/T. ratio was 10:1. NK-sensitive targets are described in Methods. Host and donor cell targets for patient R.V. were T cell blasts and for patient S.P. were EBV-LCL and T cell clones, respectively.

LCL, used as stimulators, were comparable to those of cytotoxic cells, indicating that the frequency of host-reactive cells is high, although somehow lower, compared to the frequencies of
$\mathrm{T}$ cells specific for alloantigens. In patient S.P. the frequencies of cytotoxic and IL-2 producing $T$ cells reactive against the host EBV-LCL (SPS) were 1:348 and 1:161, respectively, which were comparable to the frequencies of cells reactive against the allogeneic EBV-LCL (K395). In contrast, the reactivity against the 1st donor EBV-LCL SPA2 was low and comparable to the frequencies of autoreactive cells in normal donors (19) and those found in donor MB tested in parallel (Table VIII).

Determination of host and donor-reactivity in the TCR $\gamma \delta T$ cell compartment. The specificity and function of TCR $\gamma \delta^{+} \mathrm{T}$ cells is not well understood. A possible role of TCR $\gamma \delta^{+} \mathrm{T}$ cells in immune surveillance has been suggested (32). On the other hand, donor derived TCR $\gamma \delta^{+} \mathrm{T}$ cell clones capable of killing autologous TCR $\alpha \beta^{+}$T cells have been described in recipient of allogeneic BMT (33). To address the question whether donor derived TCR $\gamma \delta^{+} \mathrm{T}$ cells display cytotoxic activity against the donor derived cells, TCR $\gamma \delta^{+} \mathrm{T}$ cell clones from PBMC of both patients were established. The phenotype and the lytic activity of five representative TCR $\gamma \delta^{+} \mathrm{T}$ cell clones from each patient are shown in Table IX. All $20 \mathrm{TCR} \gamma \delta^{+} \mathrm{T}$ cell clones isolated from patient R.V. were, as expected, $\mathrm{V} \delta 2^{+}$since no $\mathrm{V} \delta 1 \mathrm{~T}$ cells were detected in the freshly isolated PBMC (not shown). 2 of the $10 \mathrm{TCR} \gamma \delta^{+} \mathrm{T}$ cell clones isolated from patient S.P. did not react with the $\delta \mathrm{TCS}_{1}$ or BB3 mAbs, recognizing the $\mathrm{V} \delta 1$ and $\mathrm{V} \delta 2$ forms of the receptor respectively (16). All $30 \mathrm{~T}$ cell clones tested were cytotoxic for K 562 but none of them were cytotoxic for host-reactive $\mathrm{T}$ cell clones or $\mathrm{T}$ cell blasts of the donor. In addition, no cytotoxic activity for host $\mathrm{T}$ cells and host EBVLCL was observed. Collectively, these results indicate that the $\mathrm{TCR} \gamma \delta^{+} \mathrm{T}$ cells are not associated with any antihost or antidonor reactivity.

\section{Discussion}

We have studied the chimerism and the development of donor $T$ cell repertoire in two SCID patients reconstituted with HLAmismatched allogeneic fetal liver stem cell transplantations. Both patients suffered from SCID with a selective T cell defect and normal numbers of $B$ cells and were transplanted during the first year of life. They received multiple transplants, from different unrelated donors, and in many cases the fetal liver cells were injected together with a cell suspension obtained from the autologous thymus. These conditions increase the probability of engraftment, since they allow the injection of a high number of cells which may find proper support for growth

Table III. Proliferative Response of PBMC of Patients R.V. and S.P. to Host, Parental, and Allogeneic Cells

\begin{tabular}{|c|c|c|c|c|c|c|}
\hline & \multicolumn{6}{|c|}{ Stimulator ${ }^{*}$} \\
\hline & Medium & Host & Mother & Father & Allogeneic & Allogeneic \\
\hline & \multicolumn{6}{|c|}{$c p m \times 10^{-3}$ of $\beta^{3} H J T d R$ incorporation } \\
\hline R.V. & $0.6 \pm 0.0^{\S}$ & $1.4 \pm 0.3$ & $64.7 \pm 3.5$ & $40.0 \pm 5.8$ & $54.3 \pm 1.2$ & $75.6 \pm 5.6$ \\
\hline G.A. ${ }^{\ddagger}$ & $8.3 \pm 0.1$ & $309.8 \pm 16.1$ & $354.9 \pm 7.5$ & $409.4 \pm 17.3$ & $293.2 \pm 4.2$ & $466.2 \pm 20.0$ \\
\hline S.P. & $1.7 \pm 0.3$ & $4.1 \pm 0.1$ & $12.1 \pm 0.4$ & ND & $24.6 \pm 2.0$ & $22.4 \pm 2.2$ \\
\hline P.P. $\ddagger$ & $2.1 \pm 0.5$ & $38.6 \pm 1.1$ & $22.7 \pm 0.6$ & ND & $47.2 \pm 3.7$ & $36.0 \pm 2.9$ \\
\hline
\end{tabular}

* EBV-LCL for patient R.V. and monocytes for patient S.P. were used as stimulators.

${ }^{\ddagger}$ Normal donors PBMC tested in parallel.

${ }^{\S}$ Mean \pm SD. 
Table IV. Effect of aCD28 $m A b, I L-2$, and IL-4 on Specific Unresponsiveness of SP-PBMC

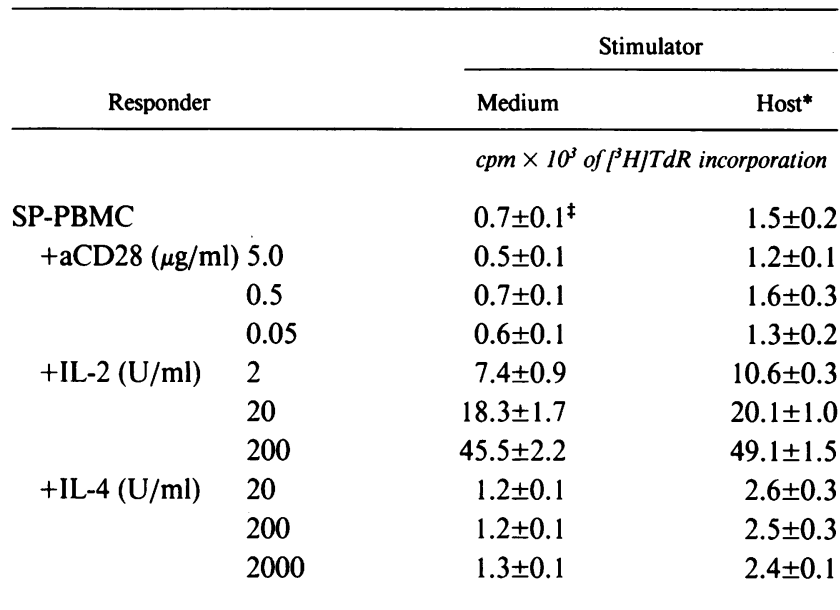

* Monocytes were used as stimulators.

${ }^{\ddagger}$ Mean \pm SD.

and differentiation in the autologous thymic stromal cells (4). In patient S.P., who received two fetal liver and thymus transplants, stem cells from both donors engrafted. However, only after the second transplant a significant clinical improvement was observed, which is compatible with the observation that $80 \%$ of the T cells have the HLA phenotype of the second donor (21). Patient R.V. received seven transplants and in four of them the autologous thymus was simultaneously injected. Of these transplants only one engrafted. The reason for this selective engraftment remains unclear. The number of the cells injected may be an important factor. In contrast, because the HLA type of the pretransplanted fetal cells was not available, we could not determine whether the presence of the fetal thymus or certain HLA combinations between host and donor cells may have played a role in determining successful engraftment.

In patient R.V., as in other patients, the time frame of reconstitution was relatively slow. A stable normalization of the percentages of peripheral mature $T$ cell subsets was detected four months after the first transplant. This could be due to the injection of cell suspensions containing only highly immature cells or to a greater difficulty of allogeneic stem cells to differentiate in a mismatched environment. In line with these explanations is the observation that the time required for the appearance of functional lymphoid cells is much longer after $\mathrm{T}$ cell depleted haploidentical bone marrow stem cells than after unfractionated HLA-identical marrow cell transplantation (7). A persistent inverted $\mathrm{CD}^{+} / \mathrm{CD}^{+}$ratio is a common finding after FLT, whereas after BMT the appearance of $\mathrm{CD}^{+}$cells precedes that of $\mathrm{CD} 4^{+}$cells only during the early phase of reconstitution and the $\mathrm{CD} 4^{+} / \mathrm{CD}^{+}$ratio rapidly becomes normal $(7,34)$. A high percentage of TCR $\gamma \delta^{+}$cells was observed in the peripheral blood of patient R.V. $3 \mathrm{yr}$ after transplantation. They represented $40 \%$ of the $\mathrm{CD}^{+}$cells and they de-

Table V. Proliferative Responses, Cytotoxic Activity, and IFN- $\gamma$ Production of Donor-derived RV-T Cell Clones to Host derived EBVLCL (UD153) and T Cell Blasts

\begin{tabular}{|c|c|c|c|c|c|}
\hline \multirow[b]{2}{*}{$\begin{array}{l}\mathrm{T} \text { cell } \\
\text { clones }\end{array}$} & \multirow[b]{2}{*}{ Phenotype } & \multirow[b]{2}{*}{$\begin{array}{l}\text { Proliferation } \\
\text { with UD153 }\end{array}$} & \multicolumn{2}{|c|}{ Cytotoxicity* } & \multirow[b]{2}{*}{$\begin{array}{l}\text { IFN- } \gamma \text { production } \\
\text { with UD153 }\end{array}$} \\
\hline & & & UD153 & $\mathrm{T}$ blasts & \\
\hline & & $c p m \times 10^{-36}$ & & & $n g / m l$ \\
\hline RV-A47 & $\mathrm{CD}^{+}{ }^{+}$ & 37.2 & 0 & 0 & 5.2 \\
\hline RV-B11 & $\mathrm{CD}^{+}{ }^{+}$ & 27.7 & 10 & 5 & 30.4 \\
\hline RV-B39 & $\mathrm{CD}^{+}$ & 3.1 & 3 & 3 & 5.3 \\
\hline RV-B46 & $\mathrm{CD}^{+}$ & 2.6 & 2 & 7 & 7.3 \\
\hline RV-B51 & $\mathrm{CD}^{+}$ & 42.2 & 0 & 0 & 18.6 \\
\hline RV-C4 & $\mathrm{CD}^{+}$ & 9.6 & 0 & 0 & 27.7 \\
\hline RV-C10 & $\mathrm{CD}^{+}$ & 31.5 & 1 & 2 & 14.5 \\
\hline RV-C65 & $\mathrm{CD}^{+}$ & 27.0 & 1 & 0 & 18.3 \\
\hline RV-C85 & $\mathrm{CD}^{+}$ & 7.5 & 3 & 1 & 7.8 \\
\hline RV-C114 & $\mathrm{CD}^{+}$ & 4.7 & 2 & 2 & 9.3 \\
\hline RV-A3 & $\mathrm{CD}^{+}$ & 0.4 & 42 & 50 & 4.2 \\
\hline RV-A13 & $\mathrm{CD}^{+}$ & 1.3 & 13 & 18 & 2.5 \\
\hline RV-A24 & $\mathrm{CD}^{+}$ & 0.9 & 12 & 33 & 3.7 \\
\hline RV-A26 & $\mathrm{CD}^{+}$ & 1.3 & 26 & 17 & 9.1 \\
\hline RV-A43 & $\mathrm{CD}^{+}$ & 3.4 & 32 & 30 & 12.2 \\
\hline RV-B22 & $\mathrm{CD}^{+}$ & 0.3 & 47 & 65 & 1.1 \\
\hline RV-B36 & $\mathrm{CD}^{+}$ & 0.3 & 23 & 24 & 10.4 \\
\hline RV-B37 & $\mathrm{CD}^{+}$ & 1.1 & 14 & 22 & 8.4 \\
\hline RV-B44 & $\mathrm{CD}^{+}$ & 0.3 & 15 & 29 & 8.3 \\
\hline RV-B48 & $\mathrm{CD}^{+}$ & 0.2 & 16 & 41 & 32.9 \\
\hline
\end{tabular}

* E/T ratio $=10: 1$.

‡ No spontaneous lymphokine production was observed by unstimulated $\mathrm{T}$ cell clones.

Values represent the mean $\left[{ }^{3} \mathrm{H}\right] \mathrm{TdR}$ incorporation of triplicate cultures. 
Table VI. Cytotoxic Activity of Donor-derived $C D 8^{+} T$ Cell Clones against Host, Parents, and Donor T Cell Blasts

\begin{tabular}{lrrrr}
\hline & \multicolumn{4}{c}{ T cell blasts } \\
\cline { 2 - 5 } T cell clones & Host & Father & Mother & Donor \\
\hline & \multicolumn{5}{c}{ \% lysis* } \\
RV-A3 & 37.1 & 0.1 & 38.7 & 0.0 \\
RV-A24 & 26.5 & 36.8 & 0.5 & 0.2 \\
RV-B22 & 63.6 & 1.2 & 65.7 & 0.1 \\
RV-B36 & 14.5 & 2.1 & 9.6 & 0.3 \\
RV-B37 & 21.4 & 0.6 & 22.6 & 0.9 \\
RV-B44 & 29.4 & 17.9 & 4.7 & 0.0 \\
RV-B48 & 38.9 & 0.4 & 35.3 & 0.7 \\
RV-2/3 & 24.1 & 12.3 & 0.0 & 0.1 \\
RV-2/7 & 8.7 & 12.8 & 0.0 & 0.4 \\
RV-2/13 & 34.3 & 20.2 & 1.1 & 1.9 \\
& & & & \\
\hline
\end{tabular}

$* \mathrm{E} / \mathrm{T}$ ratio $=10: 1$

creased to $26 \% 1 \mathrm{yr}$ later. These high percentages of TCR $\gamma \delta^{+} \mathrm{T}$ cells were only observed in patient R.V. and not in patient S.P., or in other patients treated with fetal liver stem cells. In normal donors the TCR $\gamma \delta^{+} \mathrm{T}$ cells can be divided in two distinct populations based on $\mathrm{V} \delta 1$ or $\mathrm{V} \delta 2$ expression $(12,35,36)$. The $\mathrm{V} \delta 1^{+}$ subset is predominant in the thymus and in cord blood, whereas the proportion of the $\mathrm{V} \delta 2^{+}$subset progressively increases in the peripheral blood after birth. In children and adults $>70 \%$ of the TCR $\gamma \delta^{+} \mathrm{T}$ cells present in the peripheral blood are $\mathrm{V} \delta 2^{+}$. The $\mathrm{V} \delta 2^{+} \mathrm{TCR} \gamma \delta^{+} \mathrm{T}$ cells have high expression of the memory cell marker CD45RO, whereas the $\mathrm{V} \delta 1^{+}$ cells are CD45RA ${ }^{+}$. The $\mathrm{V} \delta 2^{+}$cells appear to represent an $\mathrm{Ag}$ responding population of $\mathrm{TCR} \gamma \delta^{+} \mathrm{T}$ cells and it has been demonstrated that their expansion results from nongenetic environmental stimulation by antigens such as mycobacteria $(12,36)$. Interestingly, in patient R.V. all $\mathrm{TCR} \gamma \delta^{+} \mathrm{T}$ cells were $\mathrm{V} \delta 2^{+} \mathrm{CD} 45 \mathrm{RO}^{+}$, suggesting that they represent a subset of in vivo activated cells which may have undergone abnormal expansion. High percentages of TCR $\gamma \delta^{+} \mathrm{T}$ cells have also been observed in SCID patients reconstituted after HLA-mismatched T cell-depleted BMT (37). However, these TCR $\gamma \delta^{+}$

Table VII. Lymphokine Production by Host-reactive T Cell Clones of Patient R.V. in Response to ConA*

\begin{tabular}{|c|c|c|c|c|}
\hline & \multicolumn{4}{|c|}{ T Cell clones } \\
\hline & \multicolumn{2}{|c|}{$\mathrm{CD}^{+}(n=20)^{\ddagger}$} & \multicolumn{2}{|c|}{$\mathrm{CD}^{+}(n=10)$} \\
\hline & $\begin{array}{l}\text { Mean } \\
\text { values }\end{array}$ & Range & $\begin{array}{l}\text { Mean } \\
\text { values }\end{array}$ & Range \\
\hline IL-4 $(p g / m l)$ & $<40$ & & $<40$ & \\
\hline IL-5 $(p g / m l)$ & 160 & $35-300$ & $<20$ & \\
\hline IL-2 $(p g / m l)$ & 1212 & $280-5100$ & 1130 & $190-4100$ \\
\hline IFN- $\gamma(n g / m l)$ & 21.5 & $8.3-39.5$ & 15.0 & $9.5-22.6$ \\
\hline GM-CSF $(n g / m l)$ & 6.1 & $4.0-9.1$ & 3.4 & $2.8-3.9$ \\
\hline
\end{tabular}

* ConA $=10 \mu \mathrm{g} / \mathrm{ml}$.

${ }^{\ddagger}$ Number of $\mathrm{T}$ cell clones tested.
Table VIII. Frequency of Cytotoxic and IL-2-Producing CD8 ${ }^{+} T$ Cells of Patients R.V. and S.P. to Host and Third-Party EBV-LCL

\begin{tabular}{lllc}
\hline & & \multicolumn{2}{c}{ Frequency of } \\
\cline { 3 - 4 } Responder & \multicolumn{1}{c}{$\begin{array}{c}\text { Stimulators } \\
\text { (EBV-LCL) }\end{array}$} & $\begin{array}{c}\text { Cytotoxic } \\
\text { T cells }\end{array}$ & $\begin{array}{c}\text { IL-2-producing } \\
\text { T cells }\end{array}$ \\
\hline RV-CD8 $^{+}$ & UD153 (host) & $1: 902$ & $1: 436$ \\
& K395 (allo) & $1: 179$ & $1: 128$ \\
SP-CD8 $^{+}$ & SPS (host) & $1: 348$ & $1: 161$ \\
& SPA2 (first donor) & $1: 2781$ & $1: 693$ \\
& K395 (allo) & $1: 116$ & $1: 331$ \\
MB*-CD8 $^{+}$ & MTB (auto) & $1: 6840$ & $<1: 6840$ \\
& SPS (allo) & $1: 350$ & $1: 123$ \\
& SPA2 (allo) & $1: 219$ & ND \\
\hline
\end{tabular}

* Normal donor.

T cells of BMT patients were $\mathrm{V} \delta 1$, which may reflect a lack of maturation (37). Furthermore, these $\mathrm{TCR} \gamma \delta^{+}$cells have been implicated in antidonor reactivity (38). In our case it can be ruled out that $\gamma \delta$-bearing cells are involved in antihost or antidonor reactivity $(33,38)$, because none of the $\mathrm{TCR} \gamma \delta^{+} \mathrm{T}$ cell clones tested had any activity against the donor or the host cells.

In both patients, all $\alpha \beta$ and $\gamma \delta \mathrm{T}$ cells were of donor origin, whereas B cells and monocytes, which were present before the transplants, remained of host origin. The mismatch between the $\mathrm{T}$ cell and $\mathrm{B}$ cell/monocyte populations may be responsible for the fact that the ability to produce immunoglobulins usually takes a long time to develop $(3,8)$. However, normal antibody responses can eventually be obtained in vivo and in vitro $(4,6)$. It is interesting to notice that the engraftment of only T cells, and not of B cells, is a common feature in SCID patients who have a selective defect in T lymphocyte differentiation/function, but have phenotypically and functionally normal B cells prior to the transplant. This may reflect an advantage in growth and differentiation of the donor cell population, which is originally defective in the recipient. Self-reactivity of the donor $\mathrm{T}$ cells against the donor $\mathrm{B}$ cells has also been implicated in preventing donor B cell engraftment (39-41), but this mechanism can be excluded in our patients, since donor versus donor reactivity was not observed.

In contrast to monocytes and $\mathrm{B}$ cells, the $\mathrm{CD} 3^{-} \mathrm{CD} 56^{+} \mathrm{NK}$ cell populations were of different origin. In patient S.P., all NK cells were host derived, whereas in patient R.V. they were of donor origin and no NK cells of host origin were detectable prior to, or after transplantation. These findings may imply heterogeneity in the defects affecting the two SCID patients. In the case where the NK cells were of donor origin, it could be due to a defective common progenitor of $\mathrm{T}$ and NK cells, whereas in patient S.P., in which NK cells were of host origin, the $T$ cell defect could have occurred at later stages of differentiation. This hypothesis is supported by a previous study in which a clear heterogeneity in the NK cell function among SCID patients was demonstrated (42).

The role of the NK cells in preventing engraftment of allogenic transplantation is still controversial $(3,7,8,43,44)$. It has been reported that recipient NK cells may inhibit engraftment of allogenic transplantations in mouse and human (43, 
Table IX. Phenotype and Cytotoxic Activity of TcR $\gamma \delta^{+} T$ Cell Clones from Patients R.V. and S.P.

\begin{tabular}{|c|c|c|c|c|c|c|}
\hline \multirow{2}{*}{$\begin{array}{l}\mathrm{T} \text { cell } \\
\text { clones }\end{array}$} & \multicolumn{3}{|c|}{ Phenotype } & \multicolumn{3}{|c|}{ Cytotoxicity* } \\
\hline & $\operatorname{TcR} \gamma \delta$ & $\mathrm{V} \delta_{1}$ & $\mathrm{~V} \delta_{2}$ & K562 & Host cells ${ }^{\ddagger}$ & Donor cells ${ }^{8}$ \\
\hline & \multicolumn{3}{|c|}{$\%$ positive cells } & \multicolumn{3}{|c|}{ \% lysis } \\
\hline RV-D10 & 98.7 & 0.1 & 93.1 & 14.3 & 1.5 & 1.2 \\
\hline RV-D33 & 97.8 & 0.1 & 99.5 & 12.2 & 1.2 & 0.3 \\
\hline RV-D36 & 99.4 & 0.2 & 98.3 & 14.2 & 1.0 & 0.1 \\
\hline RV-D40 & 96.2 & 0.4 & 87.5 & 35.4 & 0.2 & 0.9 \\
\hline RV-D47 & 99.1 & 3.0 & 99.1 & 46.4 & 0.6 & 1.2 \\
\hline SP-EMI2 & 98.3 & 0.7 & 99.3 & 18.3 & 0.9 & 3.9 \\
\hline SP-EMI4 & 98.3 & 0.7 & 99.1 & 32.7 & 0.6 & 2.8 \\
\hline SP-EMI24 & 97.9 & 0.6 & 4.9 & 31.7 & 3.1 & 0.5 \\
\hline SP-EMI35 & 99.1 & 1.8 & 99.2 & 29.8 & 0.1 & 1.1 \\
\hline SP-EMI53 & 98.4 & 0.3 & 98.6 & 29.4 & 0.6 & 2.5 \\
\hline
\end{tabular}

$* \mathrm{E} / \mathrm{T}$ ratio $=10: 1$.

${ }^{\ddagger} \mathrm{RV}$ T cell blasts and SP EBV-LCL were used as targets.

${ }^{\S}$ Donor-derived $\mathrm{T}$ cell clones and T cell blasts were used as targets.

44). Furthermore, it has been suggested that donor NK cells may be involved in the development of GVHD (45). However, no clear correlation between the presence of NK activity and graft failure has been observed in SCID patients transplanted with haploidentical marrow stem cells (7). Similarly, in our patients host or donor derived NK cells did not prevent the stable engraftment of donor $\mathrm{T}$ cells and the establishment of tolerance.

Engraftment of donor NK cells has already been described in marrow grafted animals, in patients undergoing allogeneic marrow transplantation for hematologic malignancies, and in SCID patients transplanted with haploidentical T cell-depleted bone marrow stem cells $(7,8,46,47)$. However, it is not clear whether the presence of donor NK cells in the host is the result of differentiation from bone marrow precursors or is due to survival of mature NK cells present in the bone marrow cell suspension. The presence of donor origin NK cells in patient $\mathrm{RV}$, appearing late after reconstitution, suggests that they derive from NK precursors present in the fetal liver. Previous studies have demonstrated that the majority of peripheral adult NK cells have high CD16 and CD57 expression, whereas a small subset of peripheral adult NK cells $(<1 \%)(22)$ and all NK cells derived from fetal liver are weakly positive or negative for CD16 and are negative for $\operatorname{CD} 57(23,25)$. Both adult and fetal NK cells do not express CD3 $\epsilon$ on the membrane $(23,24)$, but fetal NK cells are positive for the intracytoplasmic CD3e and $\mathrm{CD} 3 \delta$ proteins (23), whereas all NK cells isolated from PBMC of adult normal donors are negative (24). In addition, fetal NK cells express Leu 8. Remarkably, the phenotypic analysis of freshly isolated RV-NK cells showed that they are CD16 negative or weakly positive and display low levels of CD57 expression. This phenotype was confirmed at the clonal level, although the cells became CD57 negative which is due to in vitro culture (L. Lanier, personal communication). However, the RV-NK cells differed from fetal NK cells because they did not have cytoplasmic CD3 $\epsilon$ and $C D 3 \delta$ proteins and did not express the Leu 8 antigen. Based on these findings, we suggest that RV-NK cells are comparable to a small population of NK cells present in the adult PBMC which represent either a distinct subset of cells or an intermediate differentiation stage (22, 23). Functional analysis demonstrated that both host and donor derived NK cells had very high killing capacity although they were not cytotoxic for donor and host cells.

Despite the split chimerism and the presence of NK cells, in both patients complete tolerance was achieved and no sign of GVHD has been observed. This tolerance has also been demonstrated in vitro by the unresponsiveness of fresh PBMC to the HLA Ags of the host in a primary MLC. Mixing experiments showed that this unresponsiveness to the host was not due to suppression (Roncarolo et al., unpublished data). The lack of responsiveness of donor-derived cells to the host cells in a primary MLC occured also in chimeric patients reconstituted with haploidentical bone marrow cells $(39,48,49)$.

These observations, together with the notion that cellular cooperation between donor $\mathrm{T}$ cells and host cells occurred in vivo and in vitro $(4,6)$, suggest that donor stem cells underwent education in the host thymus. In favor of this hypothesis is the observation that in patient R.V. the thymic shadow became detectable by $\mathrm{X}$-ray after transplantation. However, hostreactive $T$ cell clones could be isolated from the PBMC of patient S.P. indicating that host-reactive $T$ cells are not deleted from the donor $T$ cell repertoire (11). This finding is extended here to patient R.V.CD4 ${ }^{+}$and $\mathrm{CD} 8^{+} \mathrm{T}$ cell clones specific for the HLA determinants expressed by the host were isolated after polyclonal or antigen stimulation, in presence of IL-2. All $\mathrm{CD}^{+} \mathrm{T}$ cell clones were strongly cytotoxic to the host cells and were specific for class I HLA determinants. The $\mathrm{CD} 4^{+} \mathrm{T}$ cell clones were mainly proliferative and recognized class II HLA antigens.

The pattern of lymphokine production by the host-reactive $T$ cell clones of patient R.V. was quite unique and comparable to that previously described for the host-reactive $\mathrm{T}$ cell clones isolated from patient S.P. (19). In both patients the host-reactive $T$ cell clones were unable to produce IL-4, whereas they produced GM-CSF, IL-2, IFN- $\gamma$, and IL- 5 and therefore they do not fit the TH1-like or TH2-like helper cell compartments. 
Whether this lack of IL-4 production contributes to the fact that these cells are non functional in vivo, remains to be clarified.

The frequencies of $\mathrm{CD}^{+}$host-reactive cells in patient S.P. were comparable to frequencies of alloreactive cells, whereas the frequencies of cells reactive against the first donor were comparable to the autoreactivity observed in normal donors (19). In patient R.V. the frequencies of $\mathrm{CD}^{+}$host-reactive cells were high, but lower than those against alloantigens. Overall, these findings exclude the possibility that the unresponsiveness observed in both patients in the primary MLC was due to a low frequency of host-reactive cells.

Interestingly, no donor reactivity could be detected. In patient R.V., no reactivity against the HLA-A2 antigen shared between the host and the donor was observed among all the $\mathrm{CD}^{+} \mathrm{T}$ cell clones tested. In patient S.P., we could not find $\mathrm{T}$ cell clones specific for HLA antigens of the first or second donor even after in vitro activation of the PBMC with EBV-LCL isolated from the first donor (Roncarolo et al., unpublished data). This lack of donor reactivity contrasts with results obtained in SCID patients transplanted with HLA haploidentical bone marrow $(38-41,49)$. The discrepancy between our data and those reported in these studies may be related to intrinsic differences between differentiation of fetal liver stem cells and bone marrow stem cells. These differences may also be due to the use of T cell clones versus PBMC or T cell lines (38). In addition, in the study where donor-reactive $\mathrm{T}$ cell clones could be isolated, they were $\mathrm{CD}^{+}{ }^{+}$and class II MHC specific, which is in line with the observation that class II MHC specific autoreactive clones can also be isolated from normal donors (50). On the other hand, we could not exclude that the presence of donor derived thymic stroma cells played a role in preventing antidonor reactivity. However, the notion that no $\mathrm{Ag}$ specific $\mathrm{T}$ cells restricted by the donor HLA could be detected argues against this hypothesis (20). In addition, as discussed below, human thymic epithelium does not induce negative selection.

Collectively, our data show that after reconstitution with allogenic fetal liver stem cells' tolerance toward both host and donor can be achieved. However, host-reactive cells are not deleted from the $\mathrm{T}$ cell repertoire of the patients, whereas donor-reactive cells are absent. This suggests that the donor cells, during their differentiation in the host environment, underwent negative selection to the donor, but not to the host HLA determinants. This can be explained by assuming that the host thymus, in which the donor $\mathrm{T}$ cell precursors differentiated, contained functional thymic epithelium, but no dendritic cells, macrophages or B cells of the host. In contrast, hematopoietic cells of donor origin, although progressively disappearing from the periphery (4), could still be present in the host thymus. This hypothesis is supported by our recent studies in SCID-hu mice transplanted with fetal liver and fetal thymus from the same or from different, HLA mismatched, donors in whom hematopoietic cells of fetal liver origin differentiate in an allogeneic thymus. Histological analysis of the structure of the "host" thymus in these SCID-hu mice showed the presence of dendritic cells, macrophages and B cells which are exclusively of fetal liver donor origin, whereas the thymic epithelium was derived from the fetal thymus donor. $T$ cells which mature in this "chimeric thymus" acquire tolerance to both donor and host, but via different mechanisms. In the SCID-hu thymus, hematopoietic cells of the donor induce tolerance to the anti- gens expressed on their membrane by clonal deletion, whereas thymic epithelial cells of the host mediate tolerance by non-deletional mechanisms, probably involving clonal anergy (19).

The mechanisms underlying the unresponsiveness of the donor derived $\mathrm{T}$ cells to the host in the MLC remain to be determined. It has been demonstrated that the stimulation via the TCR in the absence of a costimulatory signal, such as provided by CD28/B7 interaction, induces a state of $T$ cell unresponsiveness which may be an important mechanism for the establishment of peripheral tolerance in vivo $(26,27)$. This unresponsiveness can be restored by the addition of anti-CD28 $\mathrm{mAb}$ (27). In our study, addition of anti-CD28 mAb to the primary MLC did not break the unresponsiveness of the patient's PBMC to the host cells, suggesting that the lack of CD28/B7 interaction is probably not involved in maintaining in vivo tolerance. Furthermore, exogenous IL-2, which has been shown to break $T$ cell tolerance in many models $(26,28$, 29) was ineffective in restoring specific proliferation in the primary MLC of S.P. In addition, IL-4 which has T cell growthpromoting activity ( 30$)$ had no effect. However, the fact that the majority of the $\mathrm{CD}_{4}{ }^{+}$host-reactive $\mathrm{T}$ cell clones had low, or no detectable proliferative capacity in response to the relevant alloantigens may reflect some degree of dysfunction of these cells.

In conclusion, in SCID patients transplanted with allogeneic fetal liver stem cells, the donor precursor cells can mature in the allogenic environment and give rise to a complete immunoreconstitution of the host. Despite the heterogeneity of the chimerism that is established, complete tolerance is achieved between the HLA mismatched donor and host cells. However, this in vivo tolerance is not due to clonal deletion of host-reactive cells from the peripheral $\mathrm{T}$ cell repertoire of the patients, but rather to an autoregulatory mechanism of suppression or clonal anergy.

\section{Acknowledgments}

The DNAX Research Institute of Molecular and Cellular Biology is supported by Schering-Plough Corporation. We thank Dr. F. Touraine for immunological determinations; Mrs. S. Laplace for technical support; Dr. P. A. Tovo and Dr. D. Floret for the clinical follow-up of patient RV; Dr. L. Lanier and J. Phillips for helpful suggestions; Ms. J. Hermann, Mrs. J. Polakoff and Dr. J. Cupp for cell sorting; and Ms. J. Katheiser for excellent secretarial help.

\section{References}

1. Report of a World Health Organization sponsored meeting. 1989. Primary Immunodeficiency diseases. Immunodefic. Rev. 1:173-205.

2. Parkman, R. 1991. The biology of bone marrow transplantation for severe combined immune deficiency. Adv. Immunol. 49:381-410.

3. Fischer, A., P. Landais, W. Friedrich, G. Morgan, B. Gerritsen, A. Fasth, F. Porta, C. Griscelli, S. F. Goldman, R. Levinsky, et al. 1990. European experience of bone-marrow transplantation for severe combined immunodeficiency. Lancet. 336:850-854.

4. Touraine, J.-L., M.-G. Roncarolo, C. Royo, and F. Touraine. 1987. Fetal tissue transplantation, bone marrow transplantation and prospective gene therapy in severe immunodeficiencies and enzyme deficiencies. Thymus. 10:75-87.

5. Touraine, J.-L., and H. Bétuel. 1981. Immunodeficiency diseases and expression of HLA antigens. Hum. Immunol. 2:147-153.

6. Roncarolo, M.-G., J.-L. Touraine, and J. Banchereau. 1986. Cooperation between major histocompatibility complex mismatched mononuclear cells from a human chimera in the production of antigen-specific antibody. J. Clin. Invest. 77:673-680.

7. Buckley, R. H., S. E. Schiff, H. A. Sampson, R. I. Schiff, M. L. Markert, 
A. P. Knutsen, M. S. Hershfield, A. T. Huang, G. H. Mickey, and F. E. Ward. 1986. Development of immunity in human severe primary $T$ cell deficiency following haploidentical bone marrow stem cell transplantation. J. Immunol. 136:2398-2407.

8. O'Reilly, R. J., C. A. Keever, T. N. Small, and J. Brockstein. 1990. The use of HLA non identical T-cell depleted marrow transplants for correction of severe combined immunodeficiency disease. Immunodefic. Rev. 1:273-309.

9. Knobloch, C., S. F. Goldmann, and W. Friedrich. 1991.Self-nonself discrimination and repertoire selection of human $\mathrm{T}$ cells differentiated in an HLAsemiallogeneic environment following bone marrow transplantation for severe combined immunodeficiency. Eur. J. Immunol. 21:2479-2487.

10. Geha, R. S., and F. S. Rosen. 1989. The evolution of MHC restrictions in antigen recognition by $\mathrm{T}$ cells in a haploidentical bone marrow transplant recipient. J. Immunol. 143:84-88.

11. Roncarolo, M.-G., H. Yssel, J.-L. Touraine, H. Betuel, J. E. de Vries, and H. Spits. 1988. Autoreactive T cell clones specific for class I and class II HLA antigens isolated from a human chimera. J. Exp. Med. 167:1523-1534.

12. Parker, C. M., V. Groh, H. Band, S. A. Porcelli, C. Morita, M. Fabbi, D. Glass, J. L. Strominger, and M. B. Brenner. 1990. Evidence for extrathymic changes in the T cell receptor $\gamma / \delta$ repertoire. J. Exp. Med. 171:1597-1612.

13. Gebuhrer, L., J. Lambert, M. P. Labonne, I. Moliet, A. C. Freidel, H. Betuel. 1992. Alloantisera can detect some of the variants of HLA DRw 3 identified by oligotyping. Tissue Antigens. 39:42-47.

14. Roncarolo, M.-G., M. Bigler, J. B. A. Haanen, H. Yssel, R. Bacchetta, J. E. de Vries, and H. Spits. 1991. Natural killer cell clones can efficiently process and present protein antigens. J. Immunol. 147:781-787.

15. Pessano, S., H. Oettgen, A. K. Bhan, and C. Terhorst. 1985. The T3/T cell receptor complex: Antigenic distinction between the two 20-kd T3 (T3- $\delta$ and T3-є) subunits. EMBO (Eur. Mol. Biol. Organ.) J. 4:337-344.

16. Bottino, C., G. Tambussi, S. Ferrini, E. Ciccone, P. Varese, M. C. Mingarri, L. Moretta, and A. Moretta. 1988. Two subsets of human T lymphocytes expressing $\gamma / \delta$ antigen receptor are identifiable by monoclonal antibodies directed to two distinct molecular forms of the receptor. J. Exp. Med. 168:491-505.

17. Bacchetta, R., R. De Waal-Malefyt, H. Yssel., J. Abrams, J. E. de Vries, H. Spits, and M.-G. Roncarolo. 1990. Host-reactive CD4 ${ }^{+}$and $\mathrm{CD}^{+}{ }^{+} \mathrm{T}$ cell clones isolated from a human chimera produced IL-5, IL-2, IFN- $\gamma$ and granulocyte/ macrophage-colony-stimulating factor but not IL-4. J. Immunol. 144:902-908.

18. Abrams, J., M.-G. Roncarolo, H. Yssel, U. Andersson, G. J. Gleich, and J. E. Silver. 1992. Strategies of anti-cytokine monoclonal antibody development: Immunoassay of IL-10 and IL-5 in clinical samples. Immunol. Rev. 127:5-24.

19. Vandekerckhove, B. A. E., R. Namikawa, R. Bacchetta, and M.-G. Roncarolo. 1992. Human hematopoietic cells and thymic epithelial cells induce tolerance via different mechanisms in the SCID-hu mouse thymus. J. Exp. Med. 175:1033-1043.

20. Roncarolo, M.-G., H. Yssel, J.-L. Touraine, R. Bacchetta, L. Gebuhrer, J. E. de Vries, and H. Spits. 1988. Antigen recognition by MHC-incompatible cells of a human mismatched chimera. J. Exp. Med. 168:2139-2152.

21. Spits, H., J.-L. Touraine, H. Yssel, J. E. de Vries, and M.-G. Roncarolo. 1990. Presence of host-reactive and MHC-restricted T cells in a transplanted severe combined immunodeficient (SCID) patient suggest positive selection and absence of clonal deletion. Immunol. Rev. 116:101-116.

22. Nagler, A., L. L. Lanier, S. Cwirla, and J. H. Phillips. 1989. Comparative studies of human FcRIII-positive and negative natural killer cells. J. Immunol. 143:3183-3191.

23. Phillips, J. H., T. Hori, A. Nagler, N. Bhat, H. Spits, and L. L. Lanier. 1992. Ontogeny of human natural killer cells: fetal NK cells mediate cytolitic function and express cytoplasmic CD3 $\epsilon, \delta$ proteins. J. Exp. Med. 175:1055-1066.

24. Biassoni, R., S. Ferrini, I. Prigione, A. Moretta, and E. O. Long. 1988 CD3-negative lymphokine-activated cytotoxic cells express the CD3 $\epsilon$ gene. $J$. Immunol. 140:1685-1689.

25. Lanier, L., H. Spits, and J. H. Phillips. 1992. The developmental relationship between NK cells and T cells. Immunol. Today. 13:392-395.

26. Schwartz, R. H. 1990. A cell culture model for $T$ lymphocyte clonal anergy. Science (Wash. DC). 248:1349-1356.

27. Harding, F. A., J. McArthur, J. A. Gross, D. Raulet, and J. P. Allison 1992. CD28 mediated signaling costimulates murine T cells and prevents induction of Anergy in T cell clones. Nature (Lond.). 356:607-609.

28. Essery, G., M. Feldmann, and J. R. Lamb. 1988. Interleukin-2 can prevent and reverse antigen-induced unresponsiveness in cloned human $T$ lymphocytes. Immunology. 64:413-417.

29. Dallman, M. J., O. Shiho, T. H. Page, K. J. Wood, and P. J. Morris. 1991
Peripheral tolerance of alloantigen results from altered regulation of the interleukin 2 pathway. J. Exp. Med. 173:79-87.

30. Spits, H., H. Yssel, Y. Takebe, N. Arai, T. Yokota, F. Lee, K.-I. Arai, J. Banchereau, and J. E. de Vries. 1987. Recombinant interleukin 4 promotes the growth of human T cells. J. Immunol. 139:1142-1147.

31. Paliard, X., R. de Waal Malefyt, H. Yssel, D. Blanchard, I. Chrétien, J. Abrams, J. de Vries, and H. Spits. 1988. Simultaneous production of IL-2, IL-4, and IFN- $\gamma$ by activated human $\mathrm{CD}^{+}{ }^{+}$and $\mathrm{CD} 8^{+} \mathrm{T}$ cell clones. J. Immunol. 141:849-855.

32. Borst, J., R. J. van de Griend, J. W. van Oostveen, S. Ang, C. J. Meleif, J. G. Seidman, and R. L. H. Bolhuis. 1987. A T-cell receptor $\gamma /$ CD3 complex found on cloned functional lymphocytes. Nature (Lond.). 325:683-688.

33. Bensussan, A., V. David, E. Vilmer, G. Leca, and L. Boumsell. 1990 Immunodeficiency after bone marrow transplantation can be associated with autoreactive $\mathrm{T}$ cell receptor $\gamma \delta$-bearing lymphocytes. Immunol. Rev. 116:5-13.

34. Ault, K. A., J. H. Antin, D. Ginsburg, S. H. Orkin, J. M. Rappeport, M. L. Keohan, P. Martin, and B. R. Smith. 1985. Phenotype of recovering lymphoid cell populations after marrow transplantation. J. Exp. Med. 161:1483-1502.

35. Casorati, G., G. de Libero, A. Lanzavecchia, and N. Migone. 1989. Molecular analysis of human $\gamma / \delta^{+}$clones from thymus and peripheral blood. $J$. Exp. Med. 170:1521-1535.

36. Miyawaki, T., Y. Kasahara, K. Taga, A. Yachie, and N. Taniguchi. 1990. Differential expression of CD45RO (UCHL1) and its functional relevance in two subpopulations of circulating TCR- $\gamma / \delta^{+}$lymphocytes. J. Exp. Med. 171:18331838.

37. Small, T. N., C. A. Keever, R. J. O'Reilly, and N. Flomenberg. 1988 Presence of circulating $\mathrm{CD}^{+} \mathrm{T}$ cells expressing the gamma-delta $\mathrm{T}$ cell receptor following HLA-mismatched T-cell depleted BMT for severe combined immunodeficiency. Blood. 72(Suppl. 1):408a. (Abstr.)

38. Keever, C. A., N. Flomenberg, M. V. Gazzola, K. Pekle, S. Y. Yang, T. N. Small, N. H. Collins, and R. J. O'Reilly. 1990. Cytotoxic and proliferative T cell clones with antidonor reactivity from a patient transplanted for severe combined immunodeficiency disease. Hum. Immunol. 29:42-55.

39. Schiff, S. E., and R. H. Buckley. 1987. Modified responses to recipient and donor $\mathrm{B}$ cells by genetically donor $\mathrm{T}$ cells from human haploidentical bone marrow chimeras. J. Immunol. 138:2088-2094.

40. Wijnaedts, L., F. le Dest, and A. Fischer. 1989. Development of immunological functions after bone marrow transplantation in 33 patients with severe combined immunodeficiency. Blood. 74:2212-2219.

41. Dilloo, D., H. Hanenberg, E. M. Schneider, M. Hauch, W. Nürnberger, B. M. Zimmer, R. Vöhringer, P. Wernet, U. Göbel, and S. E. G. Burdach. 1992. Treatment of donor $\mathrm{T}$ cell-mediated hematopoietic suppression after haploidentical bone marrow transplantation by $\mathrm{T}$ cell modulation in a patient with severe combined immunodeficiency. Bone Marrow Transplant. 9:57-62.

42. Peter, H. H., W. Friedrich, R. Dopfer, W. Muller, C. Kortmann, W. J. Pichler, F. Heinz, and C. H. L. Rieger. 1983. NK cell function in severe combined immunodeficiency (SCID): Evidence of a common T and NK cell defect in some but not all SCID patients. J. Immunol. 131:2332-2339.

43. Trinchieri, G. 1989. Biology of natural killer cells. Adv. Immunol. 147:187-376.

44. Murphy, W. J., V. Kumar, and M. Bennet. 1987. Rejection of bone marrow allograft by mice with severe combined immunodeficiency disease. $J$. Exp. Med. 165:1212-1217.

45. Drobyski, W. R., V. Piaskowski, R. C. Ash, J. T. Casper, and R. L. Truitt. 1990. Preservation of lymphokine-activated killer activity following $T$ cell depletion of human bone marrow. Transplantation. 50:625-632.

46. Gaines, A. D., S. E. Schiff, and R. H. Buckley. 1991. Donor type natural killer cells after haploidentical $T$ cell-depleted bone marrow stem cell transplantation in a patient with adenosine deaminase-deficient severe combined immunodeficiency. Clin. Immunol. Immunopathol. 60:299-304.

47. Robertson, M. J., and J. Ritz. 1990. Biology and clinical relevance of human natural killer cells. Blood. 76:2421-2438.

48. Keever, C. A., N. Flomenberg, J. Brochstein, M. Sullivan, N. H. Collins, J. Burns, B. Dupont, and R. J. O'Reilly. 1988. Tolerance of engrafted donor T cells following bone marrow transplantation for severe combined immunodeficiency. Clin. Immunol. Immunopathol. 48:261-276.

49. De Villartay, J. P., C. Griscelli, and A. Fischer. 1986. Self-tolerance to host and donor following HLA-mismatched bone marrow transplantation. Eur. J. Immunol. 16:117-122.

50. Tilkin, A.-F., G. Vinci, J. Michon, and J.-P. Levy. 1990. Autoreactive HLA-DR-specific autoreactive T-cell clones: possible regulatory function for B lymphocytes and hematopoietic precursors. Immunol. Rev. 116:171-181. 